\title{
Direct-current Shock in Treatment of Drug-resistant Cardiac Arrhythmias
}

\author{
LAWSON MCDONALD,* M.A., M.D., F.R.C.P.; LEON RESNEKOV, $\dagger$ M.B., M.R.C.P. \\ KEVIN O’BRIEN, $\ddagger$ M.B., M.R.C.P.
}

Brit. med. F., 1964, 1, 1468-1470

\begin{abstract}
Alternating electrical current has been widely used in the treatment of ventricular fibrillation at the time of cardiac operations, and has proved successful at other times ( $\mathrm{McD}$ Donald et al., 1963). Lown et al. (1962b) have described the use of directcurrent shock both experimentally and in the treatment of patients with atrial and ventricular arrhythmias (Lown et al., 1962a). The use of direct current enables the shock to be applied at a precise moment in the cardiac cycle, since the charge is activated by the $\mathrm{R}$ wave of the electrocardiogram and timed to occur synchronously with it. Thus undesirable'effects such as ventricular fibrillation are avoided; ventricular fibrillation may theoretically occur if the shock enters the cardiac cycle during the phase of ventricular repolarization. Lown's " cardioverter," the unit that was used in this work, consists of a capacitor of 16 microfarads which is charged by a variable D.C. transformer and discharges over 2.5 milliseconds across an inductance coil, and the resistance of the body, to give an underdamped impulse.

Since many cases benefit from the conversion of atrial flutter and atrial fibrillation to sinus rhythm (Hecht et al., 1951), digitalis and quinidine are extensively used. The use of these drugs is often successful, but quinidine therapy, especially, may have serious complications (Berman et al., 1953). Early reports (Lown et al., 1962a ; Oram et al., 1963 ; O’Brien et al., 1964) indicated that the treatment of these arrhythmias with directcurrent shock might more often be successful than treatment with drugs, and also safer. In gaining experience with directcurrent shock it seemed wise initially to treat a number of patients with atrial fibrillation, atrial flutter, or atrial tachycardia in whom digitalis and quinidine had failed to restore normal rhythm. The results are reported below.
\end{abstract}

\section{Material and Method}

Fifty patients who had failed to revert to sinus rhythm after optimum drug therapy were treated with direct-current shock (see Table I). Quinidine had been used in those with atrial fibrillation to a total of $3.6 \mathrm{~g}$. in one day, given in four two-hourly doses of $900 \mathrm{mg}$. or to a point of toxicity, as shown by rapid ventricular rate, nausea, and vomiting. Patients with atrial flutter were initially treated with digoxin until nausea occurred. Patients with atrial tachycardia were treated with digitalis and quinidine.

The patients were carefully scrutinized before, during, and after the procedure. All were anticoagulated with phenindione, and direct-current shock, using Lown's cardioverter, was administered under light general anaesthesia from thiopentone, gas, and oxygen. In the earliest cases an anaesthetic was administered, with an endotracheal tube passed, and a muscle relaxant used. Experience now shows that a light general anaesthetic is all that is necessary. Quinidine, $300 \mathrm{mg}$. by mouth, was given to each patient one and a half hours before

\footnotetext{
- Physician to the London Hospital, to the Cardiac Department of the London Hospital, and to the National Heart Hospital; Lecturer to the Institute of Cardiology, London.

the Institute of Cardiology, London.
+ Senior Registrar, National Heart Hospital, London

¥ Late Registrar, National Heart Hospital, London. Present address : Green Lane Hospital, Auckland, New Zealand.

- American Optical Company.
}

the attempt at version. An electrocardiogram was taken both immediately before and after the procedure. Chest radiographs, serum transaminases (serum glutamic oxaloacetic transaminase and lactic dehydrogenase), and sedimentation rates were

\begin{tabular}{|c|c|c|c|c|c|c|}
\hline \multirow{2}{*}{$\begin{array}{l}\text { Case } \\
\text { No. }\end{array}$} & \multirow{2}{*}{$\begin{array}{l}\text { Age } \\
\text { and } \\
\text { Sex }\end{array}$} & \multicolumn{2}{|c|}{ Arrhythmia } & \multirow{2}{*}{$\begin{array}{l}\text { Heart } \\
\text { Disease }\end{array}$} & \multirow{2}{*}{$\begin{array}{l}\text { Direct } \\
\text { Current } \\
\text { Energy } \\
\text { (Wsec)* }\end{array}$} & \multirow{2}{*}{ Result } \\
\hline & & Type & Duration & & & \\
\hline 1 & $46 \mathrm{~F}$ & A. fibr. & $10 \mathrm{mths}$ & Post-op. MVD & 50,100 & SR \\
\hline 2 & $46 \mathrm{M}$ & " & 9, & Aardiomyopathy. & 100,150 & " \\
\hline $\begin{array}{l}3 \\
4\end{array}$ & $\begin{array}{l}53 \mathrm{M} \\
50 \mathrm{M}\end{array}$ & $"$ & $\begin{array}{r}3 \mathrm{yr} . \\
16 \%\end{array}$ & Alcohol & $\begin{array}{l}100,150,200 \\
100,150\end{array}$ & $"$, \\
\hline 5 & $21 \mathrm{~F}$ & & $4 \mathrm{mths}$ & $\begin{array}{l}\text { Ao. VD } \\
\text { Lone }\end{array}$ & $100,200,300$ & " \\
\hline $\begin{array}{l}6 \\
7 \\
8\end{array}$ & $\left|\begin{array}{ll}40 & M \\
46 & M \\
53 & F\end{array}\right|$ & $\begin{array}{l}\text { A. flut. } \\
\text { A. fibr. } \\
\text { " }\end{array}$ & $\begin{array}{l}1 \mathrm{mth} . \\
20 \mathrm{yr} . \\
3 \text { ” }\end{array}$ & $\begin{array}{l}\text { Post-op. ASD } \\
\text { Post-op. MVD } \\
\text { " " }\end{array}$ & $\begin{array}{l}150 \\
100 \\
150,200, \\
250,350\end{array}$ & Failure \\
\hline $\begin{array}{r}9 \\
10\end{array}$ & \begin{tabular}{ll|}
57 & $\mathrm{~F}$ \\
52 & $\mathrm{M}$
\end{tabular} & ", & $\begin{array}{l}3.5 \mathrm{yr} \text {. } \\
4 \mathrm{yr} .\end{array}$ & $\begin{array}{l}\text { Post-op. ASD } \\
\text { Cardiomyopathy. } \\
\text { Alcohol }\end{array}$ & $\begin{array}{l}150 \\
150,200 \\
250\end{array}$ & $\begin{array}{l}\text { SR } \\
" \prime\end{array}$ \\
\hline $\begin{array}{l}11 \\
12\end{array}$ & $\begin{array}{ll}33 & \mathrm{~F} \\
22 & \mathrm{M}\end{array}$ & $\begin{array}{l}\text { A. flut. } \\
\text { A. fibr. }\end{array}$ & $2 \mathrm{mths}$ & $\begin{array}{l}\text { Post-op. MS } \\
\text { Lone }\end{array}$ & $\begin{array}{l}150 \\
150,250 \\
350,400\end{array}$ & ", \\
\hline 13 & $42 \mathrm{M}$ & " & $17 \mathrm{yr}$. & ” & $\begin{array}{l}200,250,350 \\
400,400\end{array}$ & Failure \\
\hline 14 & $29 \mathrm{M}$ & $"$ & $6 "$ & Post-op. MVD & $\begin{array}{l}150,250, \\
350,400\end{array}$ & Failuret \\
\hline $\begin{array}{l}15 \\
16\end{array}$ & $\begin{array}{ll}46 & M \\
43 & M\end{array}$ & ", & $\begin{array}{l}5, " \\
1,\end{array}$ & $\begin{array}{l}\text { Cärdiomyopathy. } \\
\text { Alcohol }\end{array}$ & $\begin{array}{l}150,250 \\
150,250\end{array}$ & SR \\
\hline $\begin{array}{l}17 \\
18 \\
19 \\
20\end{array}$ & $\left|\begin{array}{ll}32 & \mathrm{M} \\
27 & \mathrm{~F} \\
52 & \mathrm{M} \\
47 & \mathrm{~F}\end{array}\right|$ & $\begin{array}{l}\text { A." flut. } \\
\text { A. fibr. } \\
\text { ", }\end{array}$ & $\begin{array}{l}8 \mathrm{mths} \\
1 \mathrm{yr} . \\
3 \cdot{ }^{2} \\
2 \cdot 5 \mathrm{yr} .\end{array}$ & $\begin{array}{l}\text { MVD, Ao. VD } \\
\text { Post-op. ASD } \\
\text { Post-op. MVD } \\
\text { Post-thyroidec. } \\
\text { MS }\end{array}$ & $\begin{array}{l}150 \\
150 \\
150,250 \\
150\end{array}$ & ", \\
\hline 21 & $53 \mathrm{M}$ & ” & $2 \mathrm{yr}$. & $\begin{array}{l}\text { MS } \\
\text { Cardiomyopathy. } \\
\text { Alcohol }\end{array}$ & 150 & " \\
\hline $\begin{array}{l}22 \\
23 \\
24 \\
25 \\
26 \\
27\end{array}$ & $\mid \begin{array}{ll}55 & \mathrm{~F} \\
42 & \mathrm{~F} \\
42 & \mathrm{~F} \\
40 & \mathrm{~F} \\
48 & \mathrm{~F} \\
49 & \mathrm{M}\end{array}$ & $\begin{array}{l}\text { ", } \\
\text { ", } \\
\text { ", }\end{array}$ & 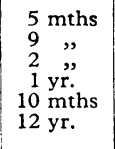 & $\begin{array}{l}\text { Post-op. MVD } \\
\text { MV̈D, A". VD } \\
\text { Post-op. MVD } \\
\text { Lone" " }\end{array}$ & $\begin{array}{l}150 \\
150 \\
150,250 \\
150 \\
150 \\
150,250, \\
350,400\end{array}$ & $\begin{array}{l}”, \\
", \\
\text { Failure }\end{array}$ \\
\hline $\begin{array}{l}28 \\
29\end{array}$ & $\begin{array}{ll}51 & M \\
50 & M\end{array}$ & $\begin{array}{l}\text { A. flut. } \\
\text { A. fibr. }\end{array}$ & $78 \%$ & Post-op. ASD & $\begin{array}{l}150 \\
150,250, \\
350,400\end{array}$ & SR \\
\hline $\begin{array}{l}30 \\
31 \\
32 \\
33 \\
34 \\
35 \\
36\end{array}$ & $\begin{array}{ll}45 & \mathrm{M} \\
57 & \mathrm{~F} \\
56 & \mathrm{~F} \\
47 & \mathrm{~F} \\
51 & \mathrm{M} \\
42 & \mathrm{M} \\
44 & \mathrm{~F}\end{array}$ & $\begin{array}{l}\text { A. flut. } \\
\text { A. tachy. } \\
\text { A. fibr. } \\
\text { "” } \\
\# \\
",\end{array}$ & 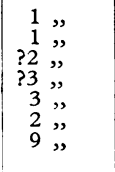 & $\begin{array}{l}\text { Post-op."MVD } \\
\text { MVD } \\
\text { Post-op. MS } \\
\text { Lone } \\
\text { MVD } \\
\text { Post-op. MVD }\end{array}$ & $\begin{array}{l}150 \\
150 \\
150,250 \\
150,250 \\
150,250 \\
155,250,100, \\
250,350\end{array}$ & $\begin{array}{l}", \\
", \\
", \\
\text { Failure }\end{array}$ \\
\hline 37 & $47 \mathrm{M}$ & " & 1, & Post-op. MS, & $25,50,150$ & SR \\
\hline $\begin{array}{l}38 \\
39\end{array}$ & $\begin{array}{ll}57 & \mathrm{M} \\
28 & \mathrm{~F}\end{array}$ & $"$ & $\begin{array}{l}7 \mathrm{mths} \\
4 \mathrm{yr} .\end{array}$ & $\begin{array}{l}\text { AD. VD } \\
\text { Post-op. MI }\end{array}$ & $\begin{array}{l}50,150 \\
50,150,250, \\
400\end{array}$ & Failure \\
\hline $\begin{array}{l}40 \\
41 \\
42 \\
43 \\
44 \\
45 \\
46\end{array}$ & $\begin{array}{ll}53 & M \\
59 & M \\
41 & M \\
49 & M \\
53 & M \\
42 & M \\
34 & F\end{array}$ & $\begin{array}{l}\text { ", } \\
\text { A."tachy. } \\
\text { A. fibr. } \\
\text { ", } \\
\text { ", }\end{array}$ & 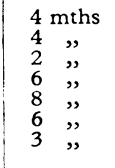 & $\begin{array}{l}\text { Lone } \\
\text { IḦD } \\
\text { MVD } \\
\text { Lone } \\
\text { M̈VD, Ao. VD, }\end{array}$ & $\begin{array}{l}150,250 \\
50,150,350 \\
150 \\
150 \\
150,250 \\
150,250,350 \\
150\end{array}$ & $\begin{array}{l}\text { SR } \\
\text { ”, } \\
\text { ”, } \\
\text { Failure } \\
\text { SR }\end{array}$ \\
\hline $\begin{array}{l}47 \\
48 \\
49 \\
50\end{array}$ & $\mid \begin{array}{ll}52 & M \\
54 & M \\
53 & M \\
26 & M\end{array}$ & $\begin{array}{l}\text { A. flut. } \\
\text { A. fibr. } \\
\text { A. flut. } \\
\text { "》 }\end{array}$ & $\begin{array}{l}1 \text { yr. } \\
1 \text { m. } \\
2 \text { mths } \\
2 \text { wks }\end{array}$ & $\begin{array}{l}\text { Hyper., MR } \\
\text { Lone } \\
\text { VैsD }\end{array}$ & $\begin{array}{l}150 \\
150 \\
150 \\
150\end{array}$ & ", \\
\hline
\end{tabular}

A. fibr. = Atrial fibrillation. A. flut. = Atrial flutter. A. tachy. $=$ Atrial tachycardia. Ao. VD. = Aortic valve disease (mild). Hyper. MR. = Systemic hypertension with functional mitral regurgitation. IHD $=$ Ischaemic heart disease. MVD $=$
Rheumatic mitral valve disease, not operated.
Post-op. $M I=M$ itral incompetence, rheumatic and bacterial endocarditis, repaired surgically. Post-op. ASD = Atria septal defect, ostium secundum, closed surgically. Post-op. MS $=$ Post-operative mitral stenosis, no significant mitral incompetence. Post-op. $M V D=$ Post-operative mitral stenosis, mitral incompetence. $S R=$ Sinus rhythm. TI = Tricuspid incomVSD = Ventricular septal defect.

* Each figure represents one shock.

t Transient sinus rhythm for 5 seconds. 
recorded before and after the shock. After successful version quinidine, $300 \mathrm{mg}$. four times a day, was administered by mouth.

Electrodes were applied to the anterior chest surfaces with the negative electrode over the apex beat and the positive at the second right interspace. Later the negative electrode was placed posteriorly, between the angle of the sternum and the spine, since less energy was then required for version. Normally the shock was initiated from the $\mathrm{R}$ wave of the electrocardiogram as noted ; when the $\mathrm{R}$ wave was of small amplitude the electrocardiographic polarity was reversed and the $S$ wave was used instead. The amount of energy delivered was from 25 to 400 watt sec. (see Table II). The maximum number of shocks given to any one patient was from one to six (see Table II). In each instance the duration of the shock was $2.5 \mathrm{~m} . \mathrm{sec}$.

\begin{tabular}{|c|c|c|c|c|c|c|c|}
\hline $\begin{array}{l}\text { No. of shocks given } \\
\text { ", patients }\end{array}$ & $\because$ & 23 & $\begin{array}{r}2 \\
13\end{array}$ & $\begin{array}{l}3 \\
5\end{array}$ & $\begin{array}{l}4 \\
7\end{array}$ & $\begin{array}{l}5 \\
1\end{array}$ & $\begin{array}{l}6 \\
1\end{array}$ \\
\hline
\end{tabular}

\section{Results}

Depolarization of the heart very briefly extinguishes electrical activity and allows the sino-atrial node to resume activity as pacemaker. The change to sinus rhythm may occur within one cardiac cycle, but the accompanying record illustrates a not infrequent series of events with intervening rhythms.

Of the 50 patients, $43(86 \%)$ reverted to sinus rhythm after direct-current shock (see Tables I and III). All the seven cases that failed to revert to sinus rhythm had atrial fibrillation; four (Cases 8, 14, 36, and 39) had mitral valve disease, and in three (Cases 13, 27, and 45) atrial fibrillation was associated interval, "wandering pacemaker," and nodal rhythm also occurred.

\section{Discussion}

Direct-current shock has been shown to be a very effective method of converting atrial fibrillation and flutter and other arrhythmias (Lown et al., 1962a ; O’Brien et al., 1964) to sinus rhythm. Present experience makes it likely to become the initial

\begin{tabular}{|c|c|c|c|c|c|c|c|}
\hline \multirow{2}{*}{$\begin{array}{c}\text { Heart } \\
\text { Disease }\end{array}$} & \multicolumn{2}{|c|}{$\begin{array}{c}\text { Atrial } \\
\text { Fibrillation }\end{array}$} & \multicolumn{2}{|c|}{$\begin{array}{l}\text { Atrial } \\
\text { Flutter }\end{array}$} & \multicolumn{2}{|c|}{$\begin{array}{c}\text { Atrial } \\
\text { Tachycardia }\end{array}$} & \multirow{2}{*}{$\begin{array}{l}\text { Total } \\
\text { Success- } \\
\text { ful } \\
\text { Version }\end{array}$} \\
\hline & Total & \begin{tabular}{|c|} 
Success- \\
ful \\
Version
\end{tabular} & Total & \begin{tabular}{|l} 
Success- \\
ful \\
Version
\end{tabular} & Total & $\begin{array}{l}\text { Success- } \\
\text { ful } \\
\text { Version }\end{array}$ & \\
\hline 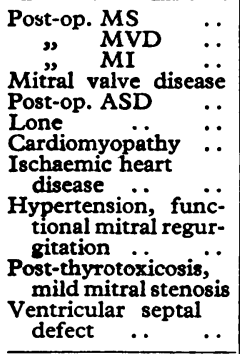 & $\begin{array}{r}3 \\
11 \\
1 \\
6 \\
2 \\
10 \\
4 \\
2\end{array}$ & $\begin{array}{l}3 \\
8 \\
6 \\
2 \\
7 \\
4 \\
2\end{array}$ & $\begin{array}{l}\frac{1}{二} \\
\overline{3} \\
2 \\
- \\
-\end{array}$ & $\frac{1}{\bar{Z}}$ & $\begin{array}{l}\overline{1} \\
\bar{三} \\
\overline{1}\end{array}$ & $\begin{array}{l}\overline{1} \\
\overline{\bar{E}} \\
\overline{\overline{1}}\end{array}$ & $\begin{array}{l}4 / 4 \\
9 / 12 \\
001 \\
6 / 6 \\
5 / 5 \\
9 / 12 \\
4 / 4 \\
3 / 3 \\
\\
1 / 1 \\
1 / 1 \\
1 / 1 \\
\end{array}$ \\
\hline Total & 40 & 33 & 8 & 8 & 2 & 2 & $43 / 50$ \\
\hline
\end{tabular}

treatment of choice for the conversion of atrial fibrillation to normal rhythm, whereas with atrial flutter a trial of digitalis still seems merited. The indications for the use of electrical shock in atrial fibrillation are essentially the same as for quinidine. However, many patients who have been fibrillating for

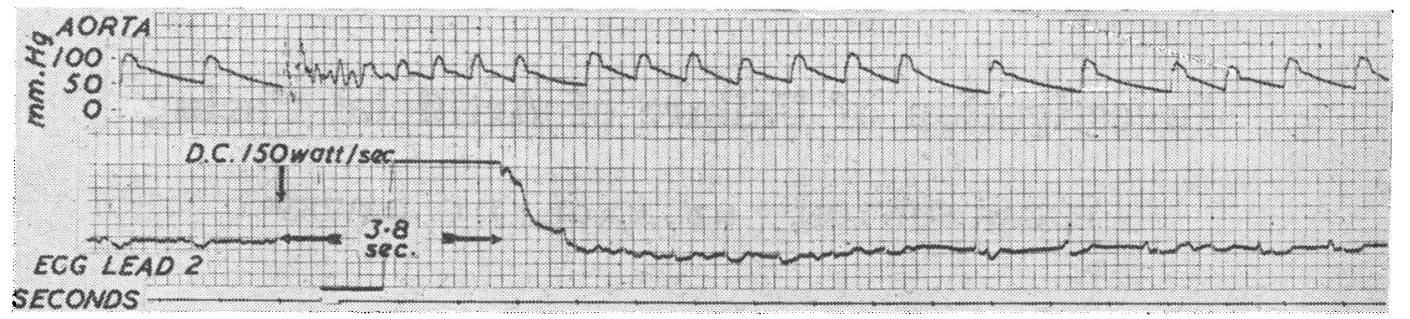

Aortic pressure-pulse (above) and lead 2 of the electrocardiogram (below) simultaneously recorded at the time of direct-current shock. Atrial fibrillation is followed by ectopic beats immediately after the shock. Subsequently there is sinus rhythm with a prolonged P-R interval, then two nodal beats, but ultimately regular sinus rhythm with a normal P-R interval is shown. Note: The electrocardiogram is lost for 3.8 seconds (electrical interference) after the shock.

with no underlying heart disease. Of the 43 patients successfully treated, 15 subsequently reverted to their original arrhythmia. In these 15 patients the heart size varied from normal to greatly enlarged, and the duration of sinus rhythm following directcurrent version ranged from one and a half hours to five months. The remaining patients have been observed in sinus rhythm for periods up to nine months.

Complications.-Complications were few in these 50 patients, and none was serious. Four patients, all of whom had atrial fibrillation with no underlying heart disease, developed transient hypotension following direct-current shock, with a systolic blood-pressure down to $80 \mathrm{~mm}$. $\mathrm{Hg}$; one of these (Case 27) had considerably elevated serum transaminases, although there was no associated clinical or electrocardiographic evidence of myocardial damage. Another (Case 3) developed transient $\mathrm{T}$-wave inversion in leads V3 to V5, without associated hypotension or elevation of serum transaminases.

Transient Intervening Rhythms.-Intervening rhythms were frequent but benign. In 15 patients frequent ectopic beats, both atrial and ventricular, occurred, and two developed atrioventricular dissociation. Bradycardia, prolongation of the $P-R$ a long time may be returned to sinus rhythm by direct-current shock, after successful mitral valvotomy, yet are resistant to quinidine. Similarly the physiological changes, such as improved cardiac output, that are brought about by conversion are likely to be no different in either form of therapy. However, certain patients with post-operative mitral incompetence, who will revert from atrial fibrillation to sinus rhythm after direct-current shock, may thereby experience a lessening of regurgitant flow through the mitral valve, and some of these cases have been completely resistant to quinidine therapy.

Experience has shown that when atrial fibrillation occurs with rheumatic heart disease and surgery is not being performed it is unwise to attempt conversion with direct-current shock. If conversion is successful there may be an undesirable increase in left atrial and pulmonary venous pressure, possibly accompanied by dyspnoea, and sinus rhythm will not be maintained for long in the natural history of the disease. Light anaesthesia for the procedure seems more desirable than allowing patients to experience the unpleasant subjective sensations that accompany directcurrent shock. Anticoagulant cover should be given to all patients where there is a substantial risk of embolism, but after 
a completely successful mitral valvotomy, or repair of an atrial septal defect, it is probably no longer needed. The effectiveness of quinidine, after conversion with direct-current shock, to lessen the relapse rate is being further studied.

No complication in the present series has been serious. Extreme care is required and proper insulation of the apparatus is essential, especially when used at the time of thoracotomy. Ventricular tachycardia and fibrillation after direct-current shock in dogs appear to be related to the height of the voltage and the amount of energy used (Peleška, 1963). Our present plan for version is to use no more than four shocks, with energy increasing from 150 to 250,350 , and 400 watt sec.

Relapse after successful direct-current shock seems most frequent if the left atrial pressure and volume remain above normal once sinus rhythm has been restored. This may occur in mitral-valve disease and in some of the cardiomyopathies. In the patients with "lone" atrial fibrillation there has been an as yet unexplained high relapse rate. Many of the patients with cardiomyopathy have been alcoholic, and failure to remove the provocative agent may contribute to their relapse. The need to repeat the procedure frequently should not arise; if the rhythm is constantly unstable, well-controlled atrial fibrillation is preferable to repeated changes of rhythm.

In conclusion, a new method of treating arrhythmias has proved better than old methods for many patients, and it should have an established place for future practice.

\section{Summary}

Fifty patients who had atrial fibrillation, atrial flutter, or atrial tachycardia, resistant to treatment with drugs, were treated with direct-current shock. In 43 of these sinus rhythm was successfully achieved. The method is described and indications and contraindications for this form of treatment are given.

Complications, which were few, are described. The results of a follow-up extending to nine months after successful treatment are given.

We wish to thank the physicians and surgeons of the National Heart Hospital, and Drs. William Barratt, Richard Bomford, and Walter Somerville, who referred patients; Drs. John Beard and Alan Gilston, who gave the anaesthetics; Sister Curry, theatre superintendent of the National Heart Hospital, and her staff for willing assistance; and $\mathrm{Mr}$. John Norman, chief technician, the Institute of Cardiology, and his staff for technical help.

ADDENDUM.-Since this paper was written a further 59 patients with arrhythmias have been treated with direct-current shock. The results in them have been similar and our conclusions the same.

\section{REFERENCES}

Berman, R., Sadaff, C. M., and Gordon, G. B. (1953). Minn. Med. 36, 1052 .

Hecht, H. H., Osher, W. J., and Samuels, A. J. (1951). f. clin. Invest., 30, 647 .

Lown, B., Amarasingham, R., and Neuman, J. (1962a). F. Amer. med. Ass., 182, 548 .

Neuman, J., Amarasingham, R., and Berkovits, B. V. (1962b). Amer. F. Cardiol., 10, 223.

McDonald, L., Resnekov, L., and Ross, D. (1963). Lancet, 2, 708.

O'Brien, K., Resnekov, L., and McDonald, L. (1964). Brit. Heart f., 26 $1,137$.

Oram, S., Davies, J. P. H., Weinbren, I., Taggart, P., and Kitchen, L. D. (1963). Lancet, 2, 159.

Peleška, B. (1963). Circulat. Res., 13, 21.

\title{
Investigation of Failure of Artificial Pacing
}

\author{
EDGAR SOWTON,*† M.D., M.R.C.P. ; J. G. DAVIES*
}

The use of artificial pacemakers in the treatment of StokesAdams disease has increased rapidly over the past few years, and many patients who were previously bedridden or suffered from recurrent syncopal attacks have been enabled to live relatively normal lives. The combination of electronic and clinical attention required by patients with artificial pacemakers can best be provided by the specialized centre where the pacemaker was originally inserted, but as the number of patients increases, the problems associated with this form of therapy are likely to be encountered in the future in many hospitals where the staff have little experience of the complications which may arise. This paper is intended to provide a guide for the initial investigation of a patient presenting with a history suggesting failure of pacing and is based on information obtained from a series of over 80 patients paced for periods of up to four years. It does not assume a knowledge of electronics, and the methods described involve the use of only simple apparatus.

There are at present four methods of artificial pacemaking in clinical use in the British Isles.

1. Long-term Electrode Catheter.-For this technique the patients carry a small pacemaker in a vest pocket or a neck sling, and this is attached to an electrode catheter which enters at the jugular vein and passes intravenously to the cavity of the right ventricle. The catheter may be "bipolar," with two electrodes at the tip, or
" unipolar," with a single-tip electrode. In the case of a unipolar catheter the second connexion from the pacemaker is made to an indifferent electrode buried in the subcutaneous tissue, usually in the neck.

2. Myocardial Wires with an External Unit.-In this case pacing is carried out through electrodes sutured surgically on to the heart and connected to a small external pacemaker by means of wires crossing the skin. This system is now rarely used for long-term pacing.

3. Completely Implanted Units.-In this technique a small selfcontained pacemaker is surgically implanted, usually in the rectus sheath, and is connected to the heart by wires which end in electrodes sutured on to the epicardium or into the cardiac muscle itself. The pacemaker contains mercury batteries with a life of two to five years, and at the end of this time the unit must be replaced surgically.

4. Induction Pacemaking.-A small receiving coil is implanted beneath the skin and connected to the heart by two electrode wires. The patient carries a small pacemaker connected to a similar coil, which is placed on the skin over the implanted coil. Power from the pacemaker is then transmitted to the heart by induction across the intact skin (Abrams, Hudson, and Lightwood, 1960).

* From the Cardiac Department, St. George's Hospital, London.

† Present address, Thorax Klin. (Fys.), Karolinska Sjukhuset, Stockholm, Sweden. 